\title{
Electromotility in Outer Hair Cells: A Supporting Role for Fast Potassium Conductance
}

\author{
Mark Ospeck Xiao-Xia Dong Jie Fang Kuni H. Iwasa \\ Biophysics Section, NIDCD, NIH, Bethesda, Md., USA
}

\section{Key Words}

Outer hair cells $\cdot$ Prestin $\cdot$ Potassium channel $\cdot$ Cochlear amplifier

\begin{abstract}
Motility of outer hair cells underlies the cochlear amplifier, which is critical for the ear's sensitivity and fine tuning. Of the two motile mechanisms present in these cells, electromotility at the lateral wall depends on the receptor potential and thus depends on currents through the cell body. We found that, in the guinea pig cochlea, basal turn outer hair cells have a fast-activating ion current $\left(\tau<0.3 \mathrm{~ms}\right.$ at $\left.23^{\circ} \mathrm{C}\right)$, which is absent in apical turn cells. This finding is consistent with our previous theoretical analysis that a fast-activating potassium current is required only in the basal turn to counteract the capacitive current and thereby to enhance the effectiveness of electromotility. Thus, our finding is consistent with the functional significance of electromotility. We conjecture therefore that the current reduces the capacitance of the outer hair cell in order to increase hearing bandwidth.
\end{abstract}

Copyright $\odot 2006$ S. Karger AG, Basel

\section{Introduction}

High sensitivity and sharp tuning of the ear requires that outer hair cells (OHCs) generate a force that counteracts viscous damping in the cochlea [1]. Such a force must be generated cycle by cycle at auditory frequencies. There are two elements in the $\mathrm{OHC}$ that are capable of high-frequency force generation. One is located in the hair bundle $[2,3]$ and the other at the lateral membrane of the cylindrical cell body [4-6]. Force generation by the hair bundle is common in frogs [2] and turtles [7]. It can be fast enough to operate cycle by cycle at high frequencies [8] and does not directly depend on the receptor potential. Force generation in the lateral membrane is based on a piezoelectric membrane motor [9] involving prestin [10]. Although this motile mechanism, which is referred to as electromotility, is intrinsically fast, it is driven by the receptor potential. Since the receptor potential is strongly attenuated by the capacitive current, so must be electromotility. Thus, the effectiveness of electromotility could be questioned (the RC time constant problem). However, the poor hearing of prestin knockout animals indicates the significance of electromotility [11]. Additionally, there is evidence for electromotility operating as a high-frequency amplifier rather than as a low-frequency feedback for optimizing the operating point of the hair bundle motor [12].

A key to the problem could be ion currents because fast voltage-gated channels could function as inductance [13] and could improve their high-frequency performance. Previous studies showed, however, that currents in OHCs activate [14-16] much more slowly than do those in inner hair cells [17] ( $\tau>10 \mathrm{~ms}$ vs. $2 \mathrm{~ms}$ at room temperature). These reports also show that OHCs' conductance does

\section{KARGER}

Fax +4161306 1234

E-Mail karger@karger.ch

www.karger.com
(C) 2006 S. Karger AG, Basel

Accessible online at: www.karger.com/orl
Kuni Iwasa

Biophysics Section, NIDCD, NIH

50th South Drive MSC 8027

Bethesda, MD 20892-8027 (USA)

Tel. +1 301496 3987, Fax +1 301480 0827, E-Mail iwasa@nih.gov 
not activate sharply near to the cells' resting membrane potential. This difference between the two kinds of hair cell conductance is paradoxical if OHCs must function as feedback motors driven by the receptor potential [5] to enhance the sensitivity and frequency selectivity of the ear [18]. Why are OHCs devoid of fast potassium currents?

To address this issue, we had previously compared viscous drag force to the force generated by electromotility of the lateral cell membrane. We found that viscous drag can effectively be counteracted by receptor potentialdriven electromotility for frequencies below about $10 \mathrm{kHz}$ [19]. This analysis suggested that OHCs in the basal turn of the guinea pig cochlea, with characteristic frequencies between 7 and $40 \mathrm{kHz}$ [20], may have fast potassium currents.

Here we report fast $\mathrm{K}^{+}$currents in basal turn OHCs. Because these cells are very difficult to maintain in our experimental chamber, the data obtained remain somewhat preliminary.

\section{Methods}

Bullae were obtained after decapitation of anesthetized guinea pigs in accordance with the animal protocol 1061-02 approved by NINDS/NIDCD. Isolated short OHCs were then obtained by dissociation of the organ of Corti. The extracellular medium contained $135 \mathrm{mM} \mathrm{NaCl}, 4 \mathrm{mM} \mathrm{KCl}, 2 \mathrm{mM} \mathrm{MgCl}_{2}, 1.5 \mathrm{mM} \mathrm{CaCl}_{2}$ and $5 \mathrm{mM}$ HEPES. Its osmolarity was adjusted with glucose to 290 $300 \mathrm{mosm} / \mathrm{kg}$ and $\mathrm{pH}$ was set to 7.4. While not used for voltage clamping, low $\mathrm{Ca}^{2+}$ external solution was applied to assist in cell dissociation. This was similar to the medium above but instead contained $4.6 \mathrm{mM} \mathrm{CaCl}_{2}$ and $5 \mathrm{mM}$ EGTA, leading to a free calcium concentration of approximately $1 \mu \mathrm{M}$. Some of the partial cell dissociations used neutral protease (dispase, Worthington Biochemical). The calculated potassium reversal potential of $-90 \mathrm{mV}$ was applied throughout.

Whole-cell voltage clamp experiments on short OHCs were performed at $23^{\circ} \mathrm{C}$. Patch pipettes were made with a pipette puller (Model 81, Sutter Instruments, Novato, Calif., USA). Access resistances of the pipettes were between 4 and $8 \mathrm{M} \Omega$ when filled with internal medium. Internal solution was $15 \mathrm{mM}$ HEPES, $140 \mathrm{~mm} \mathrm{KCl}, 1 \mathrm{~mm} \mathrm{MgCl}_{2}, 4 \mathrm{mM} \mathrm{CaCl}_{2}$, and $10 \mathrm{~mm}$ EGTA, leading to a calculated free calcium concentration between 50 and $100 \mathrm{nM}$. A patch amplifier (Axopatch 200B, Axon Instruments, Union City, Calif., USA) was used in the whole-cell voltage clamp mode and was sent a train of voltage pulse commands through an ITC-16 interface (Instrutech, Great Neck, N.Y., USA). It was driven by an Igor Pro program (Wave Metrics, Lake Oswego, Oreg., USA) with a data acquisition module created by R.J. Bookman's laboratory at the University of Miami (http://chroma.med. miami.edu/cap/).

To characterize the OHCs' conductance, we fit our cell conductance to the sum of an ohmic conductance and a voltage-de- pendent conductance that gated according to the first-order Boltzmann function $g_{0}+g /\left(1+\exp \left[-\left(V_{m}-V_{1 / 2}\right) / s\right]\right)$, with ohmic conductance $g_{0}$, gated conductance $g$, membrane potential $V_{m}$, half-activation potential $V_{1 / 2}$, and voltage sensitivity $s$.

The following are the specific experimental conditions for the 6 cells shown in the figures: (1) cell in figure 1a held at $-75 \mathrm{mV}$, capacitance $41 \mathrm{pF}$ uncompensated, access resistance of $3.7 \mathrm{M} \Omega$, voltage-insensitive conductance $2.8 \mathrm{nS}$, no protease used for dissociation; (2) cell in figure $1 \mathrm{~b}$ held at $-72 \mathrm{mV}$ by $-0.1 \mathrm{nA}$, capacitance $20 \mathrm{pF}$ uncompensated, access resistance $5 \mathrm{M} \Omega$, voltageinsensitive conductance $30 \mathrm{nS}$, no protease used for dissociation; (3) cell in figure $1 \mathrm{c}$ held at $-70 \mathrm{mV}$ by $+0.4 \mathrm{nA}$, capacitance $9 \mathrm{pF}$ $95 \%$ compensated, access resistance $6 \mathrm{M} \Omega$, voltage-insensitive conductance $30 \mathrm{nS}$, partially dissociated by $0.1 \mathrm{mg} / \mathrm{ml}$ dispase in $1 \mu \mathrm{M}$ free calcium saline for $5 \mathrm{~min}, 85 \mathrm{mM}$ of the external $\mathrm{Na}^{+}$replaced by $\mathrm{N}$-methyl-D-gluconate; (4) cell in figure $2 \mathrm{a}$ held at $-67 \mathrm{mV}$ by $-0.7 \mathrm{nA}$, capacitance $30 \mathrm{pF}$ uncompensated, access resistance $8 \mathrm{M} \Omega$, voltage-insensitive conductance $63 \mathrm{nS}$, no protease used for dissociation; (5) cell in figure $2 \mathrm{c}$ held at $-69 \mathrm{mV}$ by $-1.7 \mathrm{nA}, 19 \mathrm{pF}$ of uncompensated capacitance, access resistance $6 \mathrm{M} \Omega$, voltage-insensitive conductance $44 \mathrm{nS}$, no protease used for dissociation; (6) cell in figure $2 \mathrm{~d}$ held at $-60 \mathrm{mV}$ by $-1.5 \mathrm{nA}$, access resistance $7 \mathrm{M} \Omega, 12 \mathrm{pF}$ of capacitance $95 \%$ compensated, voltage-insensitive conductance $41 \mathrm{nS}$, partially dissociated by $0.1 \mathrm{mg} / \mathrm{ml}$ dispase in saline containing $20 \mathrm{nM}$ free calcium for $6 \mathrm{~min}, 85 \mathrm{mM}$ of the external $\mathrm{Na}^{+}$replaced by N-methyl-D-gluconate.

\section{Results}

Currents elicited from OHCs by voltage pulses are highly dependent on the turn of the cochlea from which the cells were isolated. A slow potassium current, called $I_{\mathrm{K}}$, with a half-activation voltage near $-25 \mathrm{mV}$ is known to be more prominent in apical turn cells, while a second slow potassium current, $I_{\mathrm{K}, \mathrm{n}}$, with a half-activation near $-90 \mathrm{mV}$ is known to prevail in the mid to basal turns [14-16]. Figure 1a shows an 80- $\mu \mathrm{m}$-long apical cell with a slow-activating current consistent with its being $I_{\mathrm{K}}$, having an activation time constant of approximately $15 \mathrm{~ms}$. The instantaneous current in the cell is linear (fig. 1d, e). A $30-\mu \mathrm{m}$-long $\mathrm{OHC}$ from the apical end of the basal turn also shows a slow-activating current together with a fast-activating component (fig. 1b). Very short, $25-\mu \mathrm{m}$-long basal coil cells show a prominent fast outward current (fig. 1c, 2a, d) that is not seen in longer OHCs, in addition to a slow current similar to $I_{\mathrm{K}, \mathrm{n}}$. The activation range of this fast current is $40-50 \mathrm{mV}$ more negative than that for $I_{\mathrm{K}}$ and is in the vicinity of the cells' resting potential.

The gating of this current was too fast for our wholecell voltage clamp. We instead determined an upper bound for its activation time constant. One major problem is the 


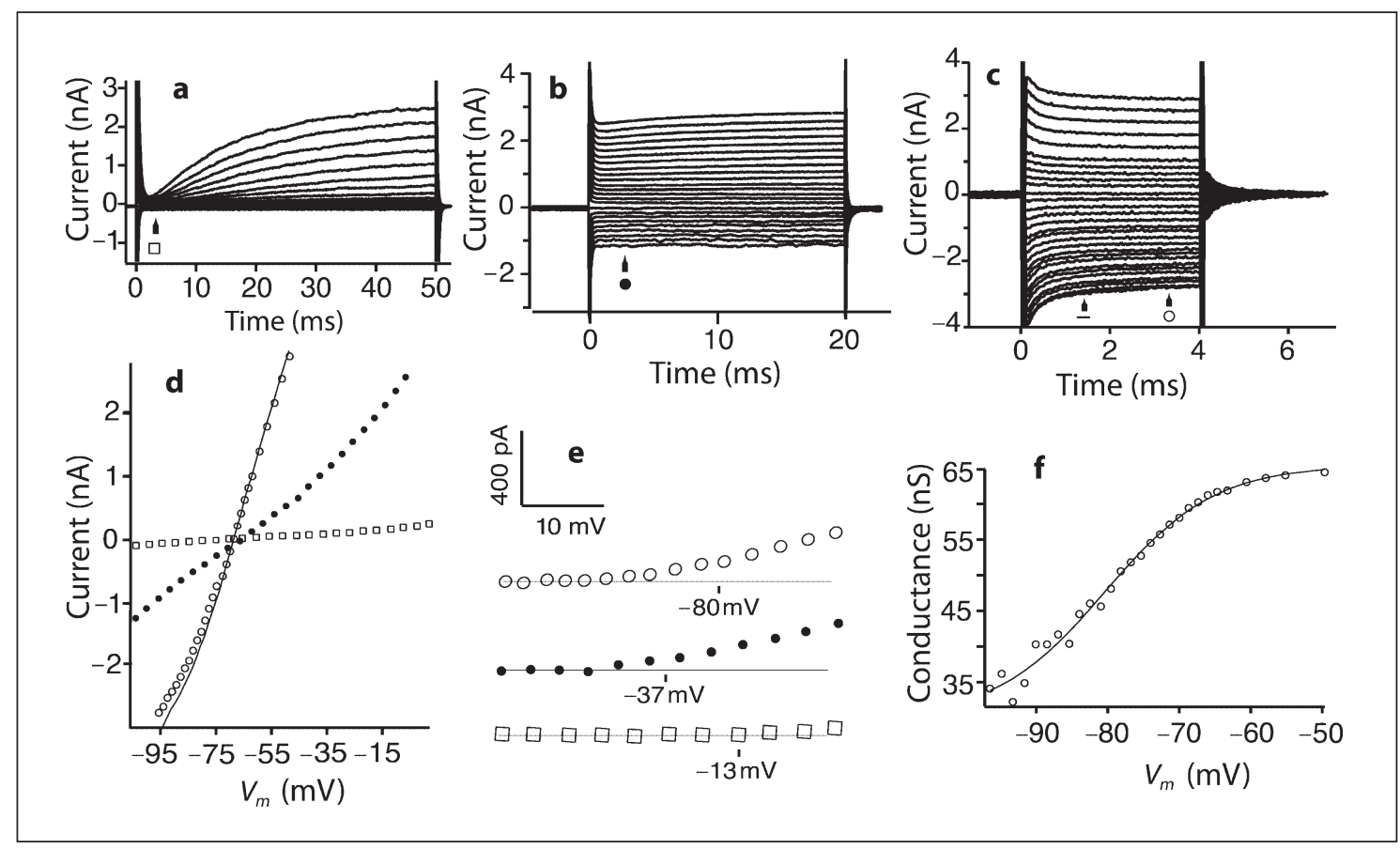

Fig. 1. Time courses of OHC currents elicited by voltage steps and their current-voltage relations. a Current time course recorded from an $80-\mu \mathrm{m}$-long cell from the apical turn. b Current time course recorded from a $30-\mu \mathrm{m}$-long cell from the apical end of the basal turn. c Currents recorded from a $22-\mu \mathrm{m}$-long basal turn cell. Arrows in $\mathbf{a}, \mathbf{b}$, and $\mathbf{c}$ indicate times at which current-voltage plots are taken. d Current-voltage plots for current recorded from a $(\square), \mathbf{b}(\bullet)$ at 3-4 ms after the voltage step and from $\mathbf{c}$ both at 1-2 (-) and 3-4 ms $(\bigcirc)$ after the step. While fitting the currentvoltage plot of $\mathbf{a}$ at $49 \mathrm{~ms}$ after the voltage step leading to a slow conductance $g=28 \pm 2 \mathrm{nS}$ with voltage sensitivity $s=6.8 \pm$ $0.5 \mathrm{mV}$, and half-activation voltage $V_{1 / 2}=-13 \pm 1 \mathrm{mV}$, the current 3-4 ms ( $\square$ ) after the step remains linear. Also fitting the currentvoltage plot of $\mathbf{b}(\bullet)$ gives a conductance $g=14 \pm 3 \mathrm{nS}$ with half-

existence of voltage-dependent membrane capacitance [21-23] due to the OHC membrane motor. This limits our electronic capacitance compensation to within a narrow voltage range. As a result, the current due to any fast conductance becomes contaminated with a capacitive transient. Therefore, we obtained current-voltage plots typically $1-2$ and 3-4 ms after the voltage step. Voltage clamp time resolution is determined by the product of a $5-\mathrm{M} \Omega$ access resistance and a cell capacitance typically around $15 \mathrm{pF}$, giving an RC time constant of $0.075 \mathrm{~ms}$. Thus, a reasonable upper bound on the current's rise time would be several time constants, or about $0.3 \mathrm{~ms}$.

This nonlinear current in short OHCs is quite labile. It fades in $20 \mathrm{~min}$ after the cell's isolation. It is particu- activation voltage $V_{1 / 2}=-37 \pm 5 \mathrm{mV}$, and a relatively weak voltage sensitivity of $20 \pm 8 \mathrm{mV}$. Note weak inward rectifying current of b (-) near to the potassium reversal potential of $-90 \mathrm{mV}$. Fitting the fast conductance $(O)$ for $c$ leads to $g=36 \pm 3 \mathrm{nS}, V_{1 / 2}=$ $-80 \pm 1 \mathrm{mV}$ and a strong voltage sensitivity $s=7.7 \pm 1 \mathrm{mV}$. The current 1-2 ms (-) after the step had similar voltage sensitivity. Standard deviation of the current data points was 14 pA. e Fast voltage-sensitive current is present only in the short, basal turn OHCs. Nonlinear current 3-4 ms after the voltage step is compared between the $80-\mu \mathrm{m}$-long cell (bottom, $\square$ ), $30-\mu \mathrm{m}$-long cell (middle, $\bullet$ ) and $22-\mu \mathrm{m}$-long cell (top, $\bigcirc$ ). First linear currents are subtracted and then the current-voltage plots are shown near their respective half-activation voltages. $\mathbf{f}$ Conductance fit for the fast current from $c$. larly susceptible to trypsin. This susceptibility likely explains its absence from an earlier report [14]. We found that partial dissociation by neutral protease (dispase, Worthington Biochemical) in a low calcium external medium retains the current. The current recorded from those cells is consistent with that obtained from cells prepared without any protease (fig. 2a, c). Blockage by tetraethylammonium (fig. 2c) demonstrates that it is a $\mathrm{K}^{+}$current. On several occasions we observed that short OHCs had both fast inward and outward rectifying currents (fig. 2d), usually with the inward currents having the weaker rectification (fig. 1d) and similar to the current seen in an in situ report [24]. 


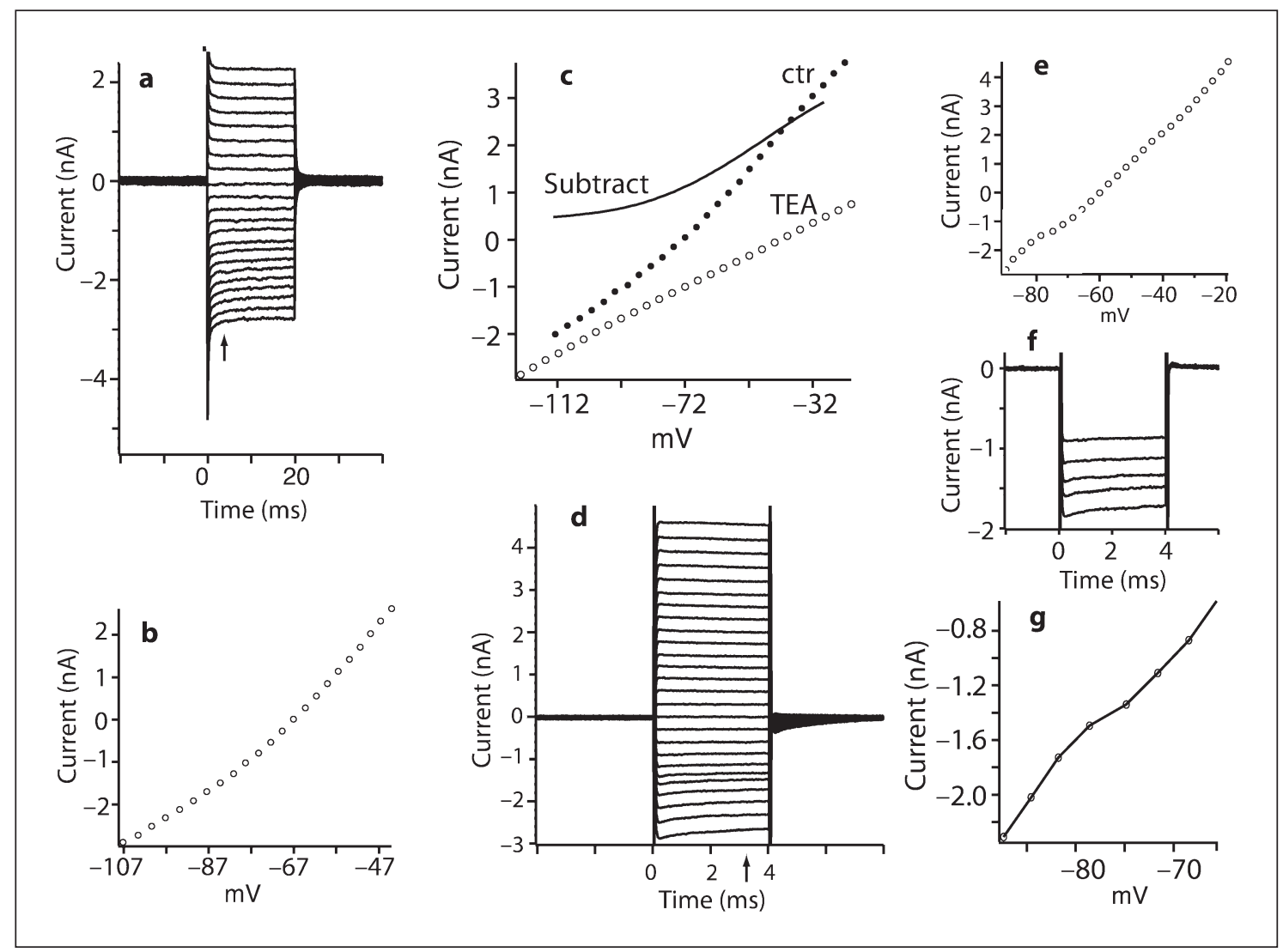

Fig. 2. Current responses to voltage steps for $25-\mu \mathrm{m}$-long OHCs from the basal turn. a Time course of currents recorded from a protease-untreated cell. b Early current (between 3 and 4 ms after the step marked by an arrow) for $\mathbf{a}$. Fit obtains $g=36 \pm 4 \mathrm{nS}, s=$ $9.4 \pm 1.8 \mathrm{mV}, V_{1 / 2}=-67 \pm 1.5 \mathrm{mV}$. For later currents recorded $18-19 \mathrm{~ms}$ after the step, $s=11.7 \pm 5 \mathrm{mV}$ (current standard deviation $14 \mathrm{pA}$ ). c Nonlinear current is abolished by $10 \mathrm{~mm}$ external TEA. Current recorded 3-4 ms after the step versus voltage for a $25-\mu \mathrm{m}$-long OHC from the cochlea's basal turn. Voltage-dependent conductance is fit by $g=25 \pm 5 \mathrm{nS}, s=11 \pm 5 \mathrm{mV}, V_{1 / 2}=$ $-69 \pm 5 \mathrm{mV}$. Current-voltage plot recorded 18-19 ms after the step

\section{Discussion}

The nonlinearity of the current elicited by voltage pulses shows an e-fold conductance increase for a voltage change ( $s$ value) of less than about $10 \mathrm{mV}$. A nonlinear $\mathrm{K}^{+}$ current with an $s$ value of less than $25 \mathrm{mV}$ cannot be due to an electrolyte asymmetry across an open pore (Goldman-Hodgkin-Katz nonlinearity) [25]. Thus, the current we observe cannot be the result of an open pore, but is due either to activation or unblocking.

What is the role of this fast current? It has long been recognized that a voltage-activated $\mathrm{K}^{+}$channel can act as is similar (standard deviations of data points $14 \mathrm{pA}$ ). d Time course of current from a short $\mathrm{OHC}$ having both inward and outward rectification. The 12-pF capacitance at the holding potential of $-60 \mathrm{mV}$ was $95 \%$ compensated. e Current-voltage plot of the current recorded 3-4 ms (marked by an arrow) after the step in $\mathbf{d}$. The outwardly rectifying conductance is characterized by $g=$ $39 \pm 2 \mathrm{nS}, s=5.1 \pm 0.6 \mathrm{mV}, V_{1 / 2}=-63 \pm 0.7 \mathrm{mV}$. Earlier current $1-2 \mathrm{~ms}$ after the step had a similar voltage sensitivity (standard deviations of data points $14 \mathrm{pA})$. $\mathbf{f}$ Nonlinear region of $\mathbf{d}$. $\mathbf{g}$ Nonlinear region of $\mathbf{e}$.

an inductance within a narrow frequency band near its activation rate [13]. Activation of such a current would lag the membrane potential by $90^{\circ}$, and thus oppose the capacitive current, which is advanced by $90^{\circ}$. Since the major part of the transducer current from the hair bundle is spent in alternately charging and discharging cell capacitance, such a fast-activating current would reduce this loss and enhance the receptor potential. To be effective in an $\mathrm{OHC}$ operating at $10 \mathrm{kHz}$, the current would require a gating time constant of about $30 \mu \mathrm{s}$ at body temperature [19]. Since at $37^{\circ} \mathrm{C}$ many ion channels gate about 3- to 4 -fold faster [25], we would then expect a time constant of about 
$0.1 \mathrm{~ms}$ at room temperature. Our experimental time resolution shows that the current gates in less than $0.3 \mathrm{~ms}$.

The attenuation of the receptor potential by membrane capacitance is not limited to OHCs in the basal turn. However, nonlinear currents in apical cells are too slow to reduce their capacitive current. Why are fast currents absent in apical cells? Assuming that OHCs supply energy to a local mechanical resonance in the cochlea, we had previously calculated that even without a fast current OHCs would nevertheless be able to counteract viscous drag up to about $10 \mathrm{kHz}$, near the low-frequency end of the basal turn [19]. Thus, only cells in the basal turn would require a fast channel.

\section{Conclusions}

We observe that there is a fast potassium current localized exclusively to the cochlea's basal turn and that it has a sharply nonlinear voltage response near to the cell's resting potential. These observations are consistent with our conjecture that the current contributes to the OHCs' receptor potential, supporting the cells' piezoelectric motor at high frequencies. However, the effectiveness of this current depends on the rise time and detailed temporal structure. Thus, the demonstration of this functional role awaits further studies.

Finally, it is likely that the presence of this conductance in the basal turn cells makes these cells labile. We speculate therefore that the presence of this conductance is a factor that contributes to high-frequency hearing loss, associated with the loss of OHCs [26, 27].

\section{Acknowledgment}

This research was supported by the Intramural Research Program of the NIDCD, NIH.

\section{References}

1 Gold T: Hearing. 2. The physical basis of the action of the cochlea. Proc R Soc Lond B Biol Sci 1948;135:492-498.

$\checkmark 2$ Martin P, Hudspeth AJ: Active hair-bundle movements can amplify a hair cell's response to oscillatory mechanical stimuli. Proc Natl Acad Sci USA 1999;96:14306-14311.

- 3 Kennedy HJ, Crawford AC, Fettiplace R: Force generation by mammalian hair bundles supports a role in cochlear amplification. Nature 2005;433:880-883.

4 Brownell W, Bader C, Bertrand D, Ribaupierre Y: Evoked mechanical responses of isolated outer hair cells. Science 1985;227: 194-196.

5 Ashmore JF: A fast motile response in guinea-pig outer hair cells: the molecular basis of the cochlear amplifier. J Physiol 1987;388: 323-347.

-6 Santos-Sacchi J, Dilger JP: Whole cell currents and mechanical responses of isolated outer hair cells. Hear Res 1988;65:143-150.

7 Fettiplace R, Ricci AJ, Hackney CM: Clues to the cochlear amplifier from the turtle ear. Trends Neurosci 2001;24:169-175.

8 Chan DK, Hudspeth AJ: $\mathrm{Ca}^{2+}$ current-driven nonlinear amplification by the mammalian cochlea in vitro. Nat Neurosci 2005;8:149155.

-9 Dong XX, Ospeck M, Iwasa KH: Piezoelectric reciprocal relationship of the membrane motor in the cochlear outer hair cell. Biophys J 2002;82:1254-1259.
10 Zheng J, Shen W, He DZZ, Long KB, Madison LD, Dallos P: Prestin is the motor protein of cochlear outer hair cells. Nature 2000;405: 149-155.

11 Liberman MC, Gao J, He DZ, Wu X, Jia S, Zuo J: Prestin is required for electromotility of the outer hair cell and for the cochlear amplifier. Nature 2002;419:300-304.

12 Liberman MC, Zuo J, Guinan JJJ: Otoacoustic emissions without somatic motility: can stereocilia mechanics drive the mammalian cochlea? J Acoust Soc Am 2004;116:16491655.

13 Hodgkin AL, Huxley AF: A quantitative description of membrane current and its application to conduction and excitation in nerve. J Physiol 1955;117:473-496.

14 Housley GD, Ashmore JF: Ionic currents of outer hair cells isolated from the guinea-pig cochlea. J Physiol 1992;448:73-98.

15 Mammano F, Ashmore JF: Differential expression of outer hair cell potassium currents in the isolated cochlea of the guineapig. J Physiol 1996;496:639-646.

16 Marcotti W, Kros CJ: Developmental expression of the potassium current IK,n contributes to maturation of mouse outer hair cells J Physiol 1999;520:653-660.

17 Kros CJ, Crawford AC: Potassium currents in inner hair cells isolated from the guinea pig cochlea. J Physiol 1990;421:263-291.
18 Patuzzi R: Cochlear micromechanics and macromechanics; in Dallos P, Popper AN Fay RR (eds): The Cochlea. New York, Springer, 1996, pp 186-257.

19 Ospeck M, Dong XX, Iwasa KH: Limiting frequency of the cochlear amplifier based on electromotility of outer hair cells. Biophys J 2003;84:739-749.

20 Greenwood DD: A cochlear frequency-position function for several species - 29 years later. J Acoust Soc Am 1990;87:2592-1605.

21 Ashmore JF: Forward and reverse transduction in guinea-pig outer hair cells: the cellular basis of the cochlear amplifier. Neurosci Res Suppl 1990;12:S39-S50.

-22 Santos-Sacchi J: Reversible inhibition of voltage-dependent outer hair cell motility and capacitance. J Neurophysiol 1991;11: 3096-3110.

23 Iwasa KH: Effect of stress on the membrane capacitance of the auditory outer hair cell. Biophys J 1993;65:492-498.

24 Russell IJ, Cody AR, Richardson GP: The responses of inner and outer hair cells in the basal turn of the guinea-pig cochlea and in the mouse cochlea grown in vitro. Hear Res 1986;22:199-216.

25 Hille B: Ion Channels of Excitable Membranes, ed 3. Sunderland, Sinauer, 2001.

26 Schuknecht HF: Pathology of the Ear. Philadelphia, Lea \& Febiger, 1993.

27 Ohlemiller KK, Gagnon PM: Cellular correlates of progressive hearing loss in 129S6/SvEv mice. J Comp Neurol 2004;469:377-390. 